\title{
PERANAN KREATIVITAS SISWA TERHADAP KEMAMPUAN MEMECAHKAN MASALAH FISIKA DALAM PEMBELAJARAN KONTEKSTUAL
}

\author{
Dwi Sambada
}

FKIP Universitas Terbuka Kampus C Unair Mulyorejo 60115

\begin{abstract}
Abstrak
Proses belajar mengajar merupakan aktivitas yang berlangsung dengan melibatkan bermacammacam komponen yang saling berinteraksi untuk mencapai tujuan yang salah satunya adalah kreativitas siswa. Untuk itu perlu dilakukan usaha perbaikan pengajaran yang lebih mendasar yang menyangkut tentang proses pemecahan masalah dalam proses belajar mengajar untuk meningkatkan prestasi belajar siswa. Penelitian ini untuk menjawab permasalahan bagaimanakah pengaruh kreativitas siswa terhadap kemampuan memecahkan masalah fisika pokok bahasan optic fisis dalam pembelajaran kontekstual. Populasi adalah seluruh siswa kelas XI SMA 3 Jombang, sedangkan sampel yang diambil adalah siswa kelas XI-A. Data penelitian dikumpulkan dengan metode tes, yaitu tes kreativitas dan tes kemampuan memecahkan masalah. Data dianalisis dengan analisis korelasi regresi sederhana diperoleh hasil penelitian sebagai berikut Terdapat hubungan yang positif dan signifikan antara kreativitas siswa terhadap kemampuan memecahkan masalah fisika pokok bahasan optic fisis dengan koefisien korelasi $\mathrm{r}=0,752$ dan diperoleh hubungan fungsional antara kreativitas dengan kemampuan memecahkan masalah yang dinyatakan dengan garis linier $\hat{Y}=8,37+0,85 X$. Hasil penelitian ini juga menunjukkan makin tinggi kreativitas makin tinggi pula kemampuan memecahkan masalah dalam pelajaran fisika. Dengan demikian usaha untuk meningkatkan mutu pendidikan perlu diarahkan pada pengembangan potensi kreativitas dalam pembelajaran.
\end{abstract}

Kata kunci: Kreativitas, kemampuan memecahkan masalah 


\section{Pendahuluan}

Kualitas pendidikan selalu ditingkatkan, salah satu cara yang dilakukan pemerintah dengan meningkatkan mutu guru dengan meningkatkan kompetensi yang dimilikinya. Kompetensi tersebut antara lain kemampuan mengaplikasikan berbagai teori belajar dalam pengajaran, kemampuan memilih dan menerapkan metode mengajar yang efektif dan efisien, dan yang paling penting kekreatifan guru untuk mampu melibatkan siswa berpartisipasi aktif dalam pembelajaran.

Fisika merupakan salah satu cabang dari ilmu pengetahuan alam yang mendasar bagi siswa untuk dapat memahami gejalagejala alam yang terjadi di sekitarnya. Ilmu Pengetahuan Alam mulai disajikan dengan harapan siswa menguasai konsep-konsep Ilmu Pengetahuan Alam dan mampu menerapkan metode ilmiah yang dilandasi sikap ilmiah untuk memecahkan masalah yang dihadapinya.

Betapa pentingnya pengembangan kreativitas dalam sistem pendidikan disebutkan pada kurikulum berbasis kompetensi bahwa untuk menghadapi tantangan perkembangan IPTEK dan informasi diperlukan sumber daya yang memiliki keterampilan tinggi yang melibatkan pemikiran kritis, sistematis, logis, kreatif dan kemampuan bekerja sama yang efektif. Kreativitas adalah hasil dari pemikiran kreatif, oleh karena itu hendaknya sistem pendidikan dapat merangsang pemikiran logis dan penalaran. Dari sini dapat diprediksi bahwa kreativitas menentukan hasil belajar.

Salah satu cara yang dapat ditempuh dalam pembelajaran fisika agar mutu pembelajaran dapat ditingkatkan adalah dengan mengintensifkan pengembangan kemampuan siswa dalam memecahkan masalah fisika sebagai pemeriksaan hasil belajar melalui proses-proses sains dengan menggunakan metode ilmiah atau metode keilmuan yang merupakan prosedur untuk mendapatkan ilmu.

Dengan pengembangan pemecahan masalah melalui proses-proses sains, siswa akan memperoleh suatu cara tentang cara menyelesaikan masalah dengan prosedur yang dilakukan para ilmuwan dalam pendapatan suatu ilmu. Dengan demikian siswa mampu menggali pengetahuanpengetahuan baru maupun ilmu-ilmu baru.

Kemampuan untuk memberikan gagasan-gagasan baru dan menerapkan dalam pemecahan masalah yang meliputi ciri-ciri kognitif seperti rasa ingin tahu, senang mengajukan pertanyaan, selalu ingin mencari pengalaman baru dapat pula dilatihkan melalui tes keativitas yang diberikan kepada siswa.

Melibatkan siswa aktif dalam pengorganisasian dan penemuan informasi pengetahuan ketika pembelajaran akan menghasilkan peningkatan pengetahuan dan peningkatan ketrampilan berfikir. Hal ini juga sesuai dengan sifat fisika yang melibatkan aktivitas kreatif dan imajinasi serta penemuan yang dapat mendorong siswa mengembangkan pemikiran divergen, orisinil, membuat prediksi dan mencoba-coba. Pembelajaran bertanya dan memecahkan masalah merupakan pangkal dari sikap kreatif siswa yang menunjukkan bahwa siswa memiliki kemampuan berkreasi dan berkarya cipta ( Eggen dan Kauchac dalam Siswono, 1999).

Kemampuan siswa untuk mengingat kembali pelajaran yang telah dipelajari sebelumnya yang berkenaan dengan suatu masalah yang diukur melalui kecepatan untuk mengingat kembali pelajaran yang dikuasai, keakuratan memiliki kreativitas, ketajaman membedakan konsep-konsep serta ketelitian dalam memecahkan masalah sangat penting dilatihkan kepada siswa.

Pendekatan Contextual Teaching And Learning ( CTL ) salah satu cara yang dapat diaplikasikan dalam proses belajar mengajar untuk mengetahui seberapa cepatkah anak itu dapat menangkap suatu materi. Dengan CTL, siswa akan dihadapkan pada materi ajar sekaligus dihadapkan pada peristiwa alam yang berhubungan dengan konten materi ajar 
tersebut. Didalam CTL, siswa diajak untuk menikmati kegiatan belajarnya dengan memenuhi rasa keingintahuan mereka.

Fisika sebagai salah satu disiplin ilmu merupakan bagian dari Natural Science disusun berdasarkan fakta, fenomenafenomena dalam hasil pemikiran dan hasil eksperimen yang telah dilakukan para ahli Fisika. Fisika tidak hanya ditandai oleh adanya kumpulan fakta atau produk saja melainkan juga ditandai munculnya metode dan sikap ilmiah. Fisika menerangkan gejala-gejala alam sesederhana mungkin dan berusaha menemukan hubungan antara kenyataan-kenyataan. Persyaratan dasar untuk pemecahan persoalannya ialah mengamati gejalagejala tersebut.

Pendidikan fisika menekankan pada pemberian pengalaman langsung untuk mengembangkan kompetensi agar siswa mampu menjelajahi dan memahami alam sekitar secara ilmiah. Pendidikan fisika diarahkan untuk "mencari tahu" dan "berbuat" sehingga dapat membantu siswa untuk memperoleh pemahaman yang lebih mendalam tentang alam sekitar.

Kreativitas dapat berkembang dengan baik jika dimulai dengan pendididkan di rumah. Orang tua harus memberikan kesempatan kepada anak untuk mengembangkan daya imajinasinya dan merangsang untuk bertanya, memperlihatkan keajaiban dunia dan kehebatan alam (Benyamin Setiawan dalam sepuluh tokoh kreativitas, 2001). Di sekolah mereka diberi kesempatan untuk melakukan eksperimen, dunia di sekeliling mereka. Anak-anak dibiasakan mencari literatur dari ensiklopedi maupun internet, sehingga dari kecil sudah terbiasa mempunyai inisiatif memecahkan masalah yang akan mereka hadapi semasa hidup. Siswa diberi kesempatan untuk belajar berpikir secara independen dan memecahkan masalah dengan menggunakan logika.

Jadi bila kreativitas dan inovasi di masyarakat ingin berkembang maka perlu diciptakan lingkungan yang menghargai kebebasan yang bertanggung jawab. Dimulai dengan pendidikan dalam keluarga dan dilanjutkan dengan pendidikan formal di sekolah dasar, menengah dan perguruan tinggi. Semuanya harus secara konsisten diprogramkan untuk meningkatkan sifat kreatif dan inovatif masyarakat secara luas (Benyamin Setiawan dalam sepuluh tokoh kreativitas, 2001).

Pada umumnya apabila seseorang menjumpai suatu masalah, maka orang tersebut akan merasa risau. Menurut John Dewey memecahan masalah itu berlangsung sebagai berikut "individu menyadari masalah bila ia dihadapkan kepada situasi keraguan dan kekaburan sehingga merasakan adanya semacam kesulitan" Hal ini disebabkan karena masalah tersebut pada dasarnya adalah mengganggu. Oleh karena itu adanya suatu masalah perlu dipecahkan atau menyelesaikan, supaya tidak terdapat lagi masalah itu sehingga tidak menganggu. Semua belajar adalah pemecahan masalah, sedang pemecahan masalah adalah sejumlah tugas yang agak kompleks yang telah diidentifikasi sebagai suatu nama lain (dalam Fatichatunnaiyirah), Orang lain memberi batasan terhadap pemecahan masalah sebagai sesuatu yang lebih komplek, yang mana para individu harus mengarah pada suatu tujuan yang tidak gampang atau tidak segera dapat dicapai.

Jadi dapat disimpulkan bahwa pemecahan masalah dapat diartikan sebagai proses menghilangkan masalah yang ada, dimana didalamnya terdapat hubungan atau konsep-konsep yang diperolehnya dalam memecahkan masalah

Pemecahan masalah fisika adalah suatu metode penyelesaian terhadap sejumlah tugas yang berkaitan dengan fisika, sedangkan kemampuan memecahkan masalah dalam pelajaran fisika adalah kemampuan menggunakan suatu metode untuk menyelesaikan sejumlah tugas dalam pelajaran fisika. 
Berdasarkan hal-hal tersebut di atas maka pertanyaan penelitian yang akan dijawab dalam penelitian ini adalah:

- Apakah terdapat pengaruh positif antara kreativitas siswa terhadap kemampuan memecahkan masalah fisika pokok bahasan optic fisis dalam pembelajaran kontekstual pada siswa kelas XI-A SMA 3 Jombang?

- Bagaimana peranan kreativitas siswa terhadap kemampuan memecahkan masalah dalam pelajaran fisika dalam pembelajaran yang kontekstual?.

Tujuan yang ingin dicapai dalam penelitian ini adalah:

- Untuk mendeskripsikan peranan kreativitas siswa terhadap kemampuan memecahkan masalah fisika pada pokok pembiasan optic fisis dalam pembelajaran kontekstual.

- Untuk mendeskripsikan tingkat kreativitas dan kemampuan memecahkan masalah pada pokok bahasan optic fisis yang dimiliki siswa SMA 3 Jombang.

Hasil penelitian ini diharapkan dapat digunakan sebagai bahan pertimbangan dalam pelaksanaan proses belajar mengajar fisika yang meningkatkan kreativitas siswa dan kemampuan pemecahan masalahmasalah fisika.

\section{Metode Penelitian}

Penelitian ini mencari hubungan antara kreativitas dengan kemampuan memecahkan masalah fisika pokok bahasan optic fisis, yang termasuk jenis penelitian korelasional. Tujuan penelitian korelasional adalah untuk mengetahui sejauh mana variasi-variasi pada suatu faktor berkaitan dengan variasi-variasi pada satu atau lebih faktor lain berdasarkan pada koefisien korelasi.

Populasi dalam penelitian ini adalah siswa kelas XI SMA 3 Jombang. Penelitian ini mengambil sampel kelas XIA dengan jumlah siswa 40 siswa.

Variabel bebas dalam penelitian ini adalah hasil tes kreativitas siswa. Variabel terikat dalam penelitian ini adalah hasil tes kemampuan memecahkan masalah pokok bahasan optic fisis.

Instrumen Penelitian yang digunakan adalah tes kreativitas dan tes kemampuan memecahkan masalah. Pada instrument dilakukan tindakan melakukan analisis validitas, reliabilitas, taraf kesukaran dan daya beda. Aspek yang diamati dapat dilihat pada tabel di bawah ini.

Tabel 1. Aspek Tes Kreativitas

\begin{tabular}{|c|c|c|c|}
\hline No. & Aspek & No. & Aspek \\
\hline $\begin{array}{l}1 . \\
2 . \\
3 . \\
4 . \\
5 . \\
6 . \\
7 . \\
8 . \\
9 .\end{array}$ & $\begin{array}{l}\text { Kelancaran. } \\
\text { Keluwesan. } \\
\text { Keaslian. } \\
\text { Kepekaan. } \\
\text { Hasrat ingin mengetahui. } \\
\text { Bersikap terbuka terhadap } \\
\text { pengalaman baru. } \\
\text { Panjang akal. } \\
\text { Keinginan untuk menemukan } \\
\text { dan meneliti. } \\
\text { Cenderung lebih suka untuk } \\
\text { melakukan tugas-tugas yang } \\
\text { berat. }\end{array}$ & $\begin{array}{l}10 . \\
11 . \\
12 . \\
13 .\end{array}$ & $\begin{array}{l}\text { Mencari jawaban-jawaban yang } \\
\text { memuaskan dan komprehensif } \\
\text { Bergairah, aktif dan dedikasi dalam } \\
\text { melakukan tugas-tugasnya } \\
\text { Berfikir fleksibel } \\
\text { Menanggapi pertanyaan-pertanyaan } \\
\text { dan kebiasaan untuk memberikan } \\
\text { jawaban lebih banyak } \\
\text { Kemampuan membuat analisis dan } \\
\text { sintesis. } \\
\text { Kemampuan membentuk abstraksi } \\
\text { Memiliki semangat inkuiri. } \\
\text { Keleluasaan dalam latar belakang } \\
\text { kemampuan membaca. }\end{array}$ \\
\hline
\end{tabular}


Pengukuran terhadap kemampuan berfikir kreatif dalam pelajaran Fisika pokok bahasan optic fisis dilakukan dengan tes kreativitas. Pengukuran terhadap pemecahan masalah fisika pokok bahasan optic fisis dilakukan dengan tes kemampuan memecahkan masalah. Tes kemampuan memecahkan masalah merupakan tes hasil belajar yang penguasaannya berdasarkan pada tujuan pembelajaran fisika pokok bahasan optic fisis.

Berdasarkan jenis data yang dikumpulkan dalam penelitian ini yaitu data kuantitatif, maka digunakan analisis statistik dan analisis statistik yang digunakan adalah korelasi. Adapun langkah-langkah yang digunakan sebagai berikut: Uji Normalitas, Analisis Regresi, Analisis Korelasi.

\section{Hasil dan Pembahasan}

\subsection{Uji Normalitas}

Untuk mengetahui pola sebaran sampel dilakukan uji normalitas terhadap data yang diperoleh dari tes kreativitas dan tes kemampuan memecahkan masalah. Dengan menggunakan uji normalitas, untuk data kreativitas $\left(\mathrm{X}_{\mathrm{i}}\right)$ dan data kemampuan memecahkan masalah $\left(\mathrm{Y}_{\mathrm{i}}\right)$ diperoleh hasil sebagai berikut:

Tabel 2. Hasil Uji Normalitas Chi-Kuadrat

\begin{tabular}{|c|l|c|c|c|c|}
\hline No. & \multicolumn{1}{|c|}{ Variabel } & $\mathrm{p}$ & $\mathrm{dk}$ & $\mathrm{X}^{2}{ }_{\text {hit }}$ & $\mathrm{X}^{2}$ Tabel \\
\hline 1. & Kreativitas & 0,05 & 3 & 7,11 & 7,81 \\
2. & Kemampuan & 0,05 & 3 & 7,49 & 7,81 \\
& $\begin{array}{l}\text { memecahkan } \\
\text { masalah }\end{array}$ & & & & \\
\hline
\end{tabular}

Oleh karena harga $\mathrm{X}^{2}$ penelitian lebih kecil dari harga $\mathrm{X}^{2}$ yang diperoleh dari tabel berarti Ho diterima, sehingga dapat disimpulkan bahwa data berasal dari sampel yang berdistribusi normal.

\subsection{Uji Signifikansi Koefisien Regresi Uji Kelinieran Regresi}

Analisis uji linieritas variabel kreativitas dengan kemampuan memecahkan masalah fisika pokok bahasan optic fisis dalam penelitian ini menggunakan analisis varians. Hasil perhitungan statistik ini disajikan dalam tabel 3 berikut ini.

Tabel 3. Rekapitulasi Analisis Varians Garis Regresi

\begin{tabular}{|l|c|c|c|c|}
\hline \multicolumn{1}{|c|}{ Sumber varians } & $\mathrm{dk}$ & $\mathrm{Jk}$ & $\mathrm{KT}$ & $\mathrm{F}$ \\
\hline Total & 40 & 177153 & 177153 & \\
\hline Regresi ( a ) & 1 & 170694,22 & 170694,22 & \\
Regresi ( b/a ) & 1 & 6141,78 & 6141,78 & 736,42 \\
Residu & 38 & 316,995 & 8,34 & \\
\hline Tuna Cocok & 10 & 120,295 & 120,295 & 1,71 \\
Kekeliruan & 28 & 196,7 & 7,025 & \\
\hline
\end{tabular}

Tabel 3 di atas dapat digunakan untuk menguji signifikansi persamaan garis regresi linier dan uji linieritas antara variabel kreativitas $\left(\mathrm{X}_{\mathrm{i}}\right)$ dengan variabel kemampuan memecahkan masalah $\left(\mathrm{Y}_{\mathrm{i}}\right)$ dapat dilihat pada tabel 4 .

Tabel 4. Korelasi Linier

\begin{tabular}{|c|c|c|c|c|c|}
\hline Variabel & $\begin{array}{c}\mathrm{dk} \\
\text { pembilang }\end{array}$ & $\begin{array}{c}\mathrm{dk} \\
\text { penyebut }\end{array}$ & $\mathrm{F}_{\text {hitung }}$ & $\mathrm{F}_{\text {tabel }}$ & Kriteria \\
\hline $\begin{array}{c}\mathrm{X}_{\mathrm{i}} \text { dan } \\
\mathrm{Y}_{\mathrm{i}}\end{array}$ & 10 & 28 & 1,71 & 2,19 & linier \\
\hline
\end{tabular}


Berdasarkan tabel 4 di atas memberikan gambaran bahwa $\mathrm{F}_{\text {hit }}=1,71$ lebih kecil dari $\mathrm{F}_{\text {tab }}=2,19\left(\mathrm{~F}_{\text {hit }}<\mathrm{F}_{\text {tab }}\right)$, sehingga dapat disimpulkan antara variabel kreativitas dengan variabel kemampuan memecahkan masalah pokok bahasan optic fisis berkorelasi linier pada taraf signifikan $\alpha=$ 0,05 .

Menentukan Koefisien Persamaan Regresi
Untuk menguji hipotesis yang menyatakan terdapat hubungan positif secara signifikan antara kreativitas dengan kemampuan memecahkan masalah fisika ditunjukkan dengan analisis korelasi dan regresi linier sederhana. Dari daftar nilai tes, dengan $\mathrm{n}=$ 40 dapat diperoleh harga-harga yang diperlukan dalam menentukan koefisien persamaan garis regresi, yaitu:

Tabel 5. Jumlah keseluruhan variabel $\mathrm{X}$ dan $\mathrm{Y}$

\begin{tabular}{|c|c|c|c|c|}
\hline$\sum X i$ & $\Sigma \mathrm{Yi}$ & $\sum X i^{2}$ & $\Sigma Y i^{2}$ & $\sum X i Y i$ \\
\hline 2675 & 2613 & 187375 & 177153 & 181970 \\
\hline
\end{tabular}

Apabila harga-harga tersebut dimasukkan dalam persamaan garis regresi $\mathrm{Y}$ atas $\mathrm{X}$ : $\hat{Y}=a+b X, \quad$ maka didapatkan : $\hat{Y}=8,37+0,85 X$. Model persamaan regresi linier antara variabel $X$ dan variabel Y, di atas yaitu $\hat{Y}=8,37+0,85 X$. Model pesamaan regresi linier ini dapat digunakan untuk menentukan kemampuan memecahkan masalah fisika siswa, jika diketahui kreativitas yang dimiliki siswa tersebut. Sebaliknya, jika diketahui tingkat kraetivitas siswa akan dapat diperkirakan tingkat kemampuan memecahkan masalah
Fisika siswa. Misalnya, jika diketahui nilai kreativitas siswa sebesar 80, maka nilai kemampuan memecahkan masalah fisika siswa yang akan diperoleh adalah 75,29 dan demikian pula sebaliknya.

\subsection{Korelasi Proses Belajar Mengajar dalam Pembelajaran Kontekstual}

Pengamatan aktivitas siswa dilakukan setiap pertemuan terhadap empat kelompok yang dipilih secara acak dan dianggap mewakili siswa dalam kelas tersebut. Hasil rekapitulasi pengamatan terhadap aktivitas siswa selama kegiatan pembelajaran yang diseting pembelajaran kontekstual disajikan pada tabel 6.

Tabel 6. Persentase Aktivitas siswa dalam pembelajaran kontekstual

\begin{tabular}{|c|l|c|c|}
\hline \multirow{2}{*}{$\begin{array}{c}\text { No } \\
\cdot\end{array}$} & \multicolumn{1}{|c|}{ Aktivitas Yang diamati } & \multicolumn{2}{|c|}{$\begin{array}{c}\text { Persentase aktivitas } \\
(\%) \text { siswa pada } \\
\text { pertemuan }\end{array}$} \\
\cline { 3 - 4 } & & I & II \\
\hline 1 & Konstruktivisme ( Constructivism) & 29,44 & 10,5 \\
\hline 2 & Menemukan ( Inquiry ) & 12,5 & 21,11 \\
\hline 3 & Bertanya ( Questioning ) & 16,66 & 16,94 \\
\hline 4 & Masyarakat belajar ( Learning Community) & 12,5 & 21,38 \\
\hline 5 & Pemodelan ( Modelling ) & 11,66 & 11,66 \\
\hline 6 & Refleksi (Reflection ) & 8,33 & 8,33 \\
\hline 7 & Penilaian Authentik (Authentic Assessment ) & 8,61 & 8,61 \\
\hline
\end{tabular}

\subsection{Pengaruh kreativitas siswa terhadap kemampuan memecahkan masalah fisika}

Berdasarkan hasil perhitungan pada bagian sebelumnya terlihat bahwa kreativitas siswa berkorelasi positif dengan kemampuan memecahkan masalah fisika pokok bahasan optik fisis. Karena harga koefisien korelasi yang diperoleh apabila dikonsultasikan dengan harga kritik $r$ tabel 
product moment ternyata harga $r_{\text {hitung }}$ jauh lebih besar. Sebab dari tabel diperoleh harga titik kritik $r_{\text {tabel }}=0,312$ pada taraf signifikansi dengan $\mathrm{n}=40$, sedangkan $\mathrm{r}$ hitung $=0,752\left(r_{\text {hit }}>r_{\text {tabel }}\right)$. Dapat disimpulkan harga $r$ hitung $d i$ atas signifikan, dan berdasarkan analisis data dapat disimpulkan bahwa hipotesis penelitian diterima berarti, ada korelasi antara kreativitas dengan kemampuan memecahkan masalah fisika pokok bahasan optik fisis. Sesuai dengan kriteria interpretasi tingkat korelasi, $r=0,752$ terletak pada interval $0,800-1,000$ yang berarti tingkat kuat.

Besar hubungan ditentukan oleh koefisien determinasi $r^{2}=0,9525$ atau sebesar 95,25 \%, yaitu bahwa meningkatnya atau menurunnya kemampuan memecahkan masalah 95,25 $\%$ dapat dijelaskan oleh tingginya kreativitas siswa melalui hubungan linier yang persamaannya $\hat{Y}=8,37+0,85 X$. Penjelasan di atas menunjukkan bahwa kira-kira 95,25\% variasi kemampuan memecahkan masalah dalam pelajaran fisika pokok bahasan optik fisis yang dimiliki siswa SMA 3 Jombang dapat ditunjukkan oleh kreativitas mereka dan sisanya ditentukan oleh keadaan lain. Bertolak dari hasil penelitian yang telah diuraiakan, faktor potensi kreativitas dalam pelajaran fisika harus terus ditingkatkan. Usaha peningkatan mutu pendidikan fisika perlu diarahkan agar potensi ini dikembangkan, sehingga mampu mendorong dan mempergunakan kualitas berfikir siswa, misalnya mengembangkan laboratorium alam dan mengembangkan barang-barang bekas yang masih dapat dimanfaatkan.

\subsection{Pendeskripsian pembelajaran dalam seting pembelajaran kontekstual}

Proses belajar mengajar akan lebih menyenangkan dan lebih produktif apabila dalam pembelajaran tidak selalu diisi dengan ceramah, sementara siswa dipaksa menerima dan menghafal. Pada penelitian ini seting pembelajaran kontekstual dijadikan sebagai suatu jalan alternatif yang lebih berpihak dan memberdayakan siswa.

Sehubungan dengan rumusan masalah, dalam pembelajaran kontekstual diharapkan berdampak positif terhadap kreativitas dan kemampuan memecahkan masalah. Langkah-langkah yang diterapkan dalam penyetingan kontekstual (CTL) selama proses belajar mengajar adalah berdasarkan 7 komponen pokok. Dalam penyetingan terdapat penilaian terhadap aktivitas siswa yang didasarkan pada tujuh komponen utama.

Dari tabel 6 di atas terlihat bahwa aspek konstruktivis mengalami penurunan sementara keenam aspek selebihnya mengalami kenaikan. Pada aktivitas aspek konstruktivis mengalami penurunan 18,94 $\%$ dari pertemuan pertama sementara mengalami kenaikan dari pertemuan pertama 8,61 \% untuk aspek menemukan, $0,28 \%$ untuk aspek bertanya, 8,88\% untuk aspek masyarakat belajar, sementara tidak ada peningkatan persentase untuk aspek refleksi, pemodelan dan penilaian authentik. Setelah dikonsultasikan pada kedua pengamat terdapat beberapa faktor yang memungkinkan adanya penurunan persentase dari aktivitas aspek konstruktivis dan kenaikan dari aktivitas ketiga aspek selebihnya.

Khusus pada aktivitas aspek konstruktivisme siswa cukup antusias untuk menerima materi baru, aktivitas membaca masih mendominasi pada pertemuan pertama, hal ini dikarenakan karena materi ajar yang baru dan siswa belum begitu paham. Sementara pada pertemuan kedua aktivitas aspek konstruktivisme tidak banyak dilakukan oleh siswa, siswa cenderung lebih aktif dengan ketiga aktivitas aspek lainnya. Aktivitas aspek menemukan, bertanya, dan masyarakat belajar yang paling dominan pada pertemuan kedua, misalkan saja aktivitas aspek menemukan, siswa dalam melakukan percobaan sangat antusias, Hal ini terjadi dimungkinkan karena rasa ingin tahu siswa sehubungan 
dengan materi yang diajarkan cenderung lebih sulit, sehingga pertanyaan sering diajukan para siswa baik antara siswa dengan siswa maupun siswa dengan guru selaku peneliti. Percobaan yang cenderung lebih sulit akan memancing kreativitas siswa, dari sini nampak sekali aktivitas bertanya dan banyak refleksi-refleksi dari siswa sebagai respon siswa terhadap kegiatan yang dilakukan. Sementara pada aktivitas aspek pemodelan, dan penilaian authentik tidak ada peningkatan persentase, hal ini terjadi karena siswa pada umunya akan mengikuti aktivitas guru dan setiap kelompok akan mempresentasikan hasil percobaannya.

Dapat disimpulkan bahwa dari persentase yang dihasilkan, aktivitas siswa yang didasarkan pada tujuh komponen pembelajaran kontekstual cukup memberikan dampak yang positif terhadap kreativitas anak dan kemampuan memecahkan masalah.

\subsection{Tingkat kreativitas siswa dan}

kemampuan memecahkan masalah pada pokok bahasan optik fisis

Dalam pembahasan sebelumnya dipaparkan bahwa terdapat korelasi yang positif antara kreativitas terhadap kemam- puan memecahkan masalah, hal ini menunjukkan bahwa antara kedua variabel tersebut berbanding lurus dalam arah yang positif. Dalam penelitian ini terdapat dua kategori berdasarkan nilai yang diperoleh, yaitu apabila nilai tes kreativitasnya dalam interval 1-50 maka dikategorikan mempunyai kreativitas rendah namun apabila nilai tes kreativitasnya dalam interval 51-100 maka dapat dikategorikan mempunyai kreativitas tinggi demikian pula pada nilai kemampuan pemecahkan masalah. Berdasarkan hasil penelitian ini, terdapat 9 (sembilan) anak yang termasuk dalam kategori mempunyai kreativitas rendah dan 31 (tiga puluh satu) anak termasuk dalam kategori mempunyai kreativitas tinggi, sementara pada kemampuan pemecahan masalah terdapat 7 (tujuh) anak yang termasuk dalam kategori mempunyai kemampuan pemecahan masalah rendah dan 33 (tiga puluh tiga) anak yang termasuk dalam kategori mempunyai kemampuan pemecaham masalah tinggi.

Pada tabel di bawah ini akan disajikan daftar nilai tes kreativitas siswa dalam kategori rendah yang diikuti dengan nilai tes kemampuan memecahkan masalahnya.

Tabel 7. Daftar nilai tes kreativitas dan tes kemampuan memecahkan masalah kategori rendah

\begin{tabular}{|c|c|c|}
\hline \multirow{2}{*}{ No. } & \multicolumn{2}{|c|}{ Nilai } \\
\cline { 2 - 3 } & Kreativitas & $\begin{array}{c}\text { Kemampuan memecahkan } \\
\text { masalah }\end{array}$ \\
\hline 1 & 35 & 39 \\
\hline 2 & 40 & 43 \\
\hline 3 & 40 & 49 \\
\hline 4 & 45 & 49 \\
\hline 5 & 50 & 49 \\
\hline 6 & 50 & 49 \\
\hline 7 & 50 & 49 \\
\hline 8 & 50 & 53 \\
\hline 9 & 50 & 53 \\
\hline
\end{tabular}

Dari tabel di atas dibuat grafik hubungan yang menunjukkan bahwa terdapat nilai yang saling berhubungan antara kreativitas dengan kemampuan memecahkan masalah. 


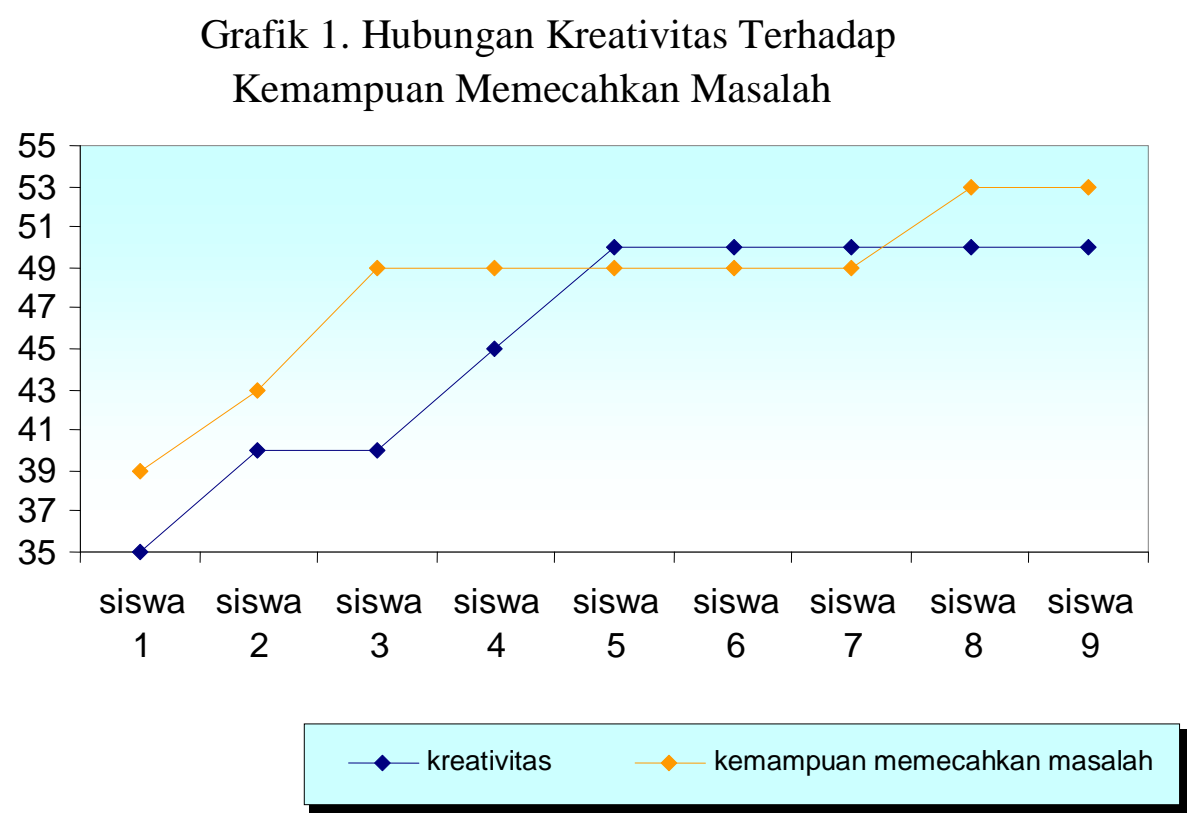

Grafik 1. Hubungan Kreativitas Terhadap Kemampuan Memecahkan Masalah (kategori rendah)

Dari tabel 7 dan grafik 1 di atas terdapat dua anak yang termasuk dalam kategori rendah untuk aspek kreativitasnya namun termasuk dalam kategori tinggi untuk aspek kemampuan memecahkan masalahnya, hal ini dapat terjadi karena beberapa faktor, faktor yang mendasar adalah dari anak itu sendiri, kita mengetahui bahwa kreativitas itu termasuk dalam kemampuan berfikir divergen dimana siswa cenderung bebas mengemukakan jawaban sesuai dengan pendapatnya, pada instrumen tes kreativitas, peneliti sengaja membuat dua kategori pertanyaan yaitu pertanyaan positif (favourable) dan pertanyaan negatif (unfavourable), jika pertanyaan positif direspon dengan pernyataan positif maka dapat diidentifikasi bahwa siswa mempunyai kreativitas tinggi begitu juga sebaliknya, hal ini mungkin juga berpengaruh pada kemampuan berfikir divergen siswa pada saat mengisi tes kreativitas, siswa kurang mempertimbangan altenatif jawaban yang lebih mengarah pada strategi pemecahan masalah serta kurang memperinci dan merumuskan kebutuhan dalam mencari informasi, sementara kemampuan memecahkan masalah termasuk dalam kemampuan berfikir konvergen yang menuntut jawaban yang benar, siswa lebih di tekankan pada ketrampilan berfikir atau kognitifnya, siswa pada aspek ini lebih ditekankan untuk memahami, mengingat, ataupun menghafal agar jawaban selalu benar dengan kenyataan. Dari sini kita dapat mengetahui bahwa tidak semua anak yang mempunyai tingkat kreativitas rendah maka akan rendah pula tingkat kemampuan memecahkan masalahnya, begitu juga dengan siswa yang mempunyai tingkat kreativitas tinggi belum tentu mempunyai tingkat kemampuan memecahkan masalahnya yang tinggi pula.

Sementara nilai yang termasuk dalam kategori mempunyai kreativitas tinggi yang diikuti dengan nilai kemampuan memecahkan masalahnya disajikan pada tabel 8 di bawah ini. 
Tabel 8. Daftar nilai tes kreativitas dan tes kemampuan memecahkan masalah kategori tinggi

\begin{tabular}{|c|c|c|}
\hline \multirow{2}{*}{ No. } & \multicolumn{2}{|c|}{ Nilai } \\
\cline { 2 - 3 } & Kreativitas & Kemampuan memecahkan masalah \\
\hline 1 & 55 & 53 \\
\hline 2 & 60 & 59 \\
\hline 3 & 60 & 59 \\
\hline 4 & 60 & 59 \\
\hline 5 & 60 & 59 \\
\hline 6 & 60 & 59 \\
\hline 7 & 60 & 59 \\
\hline 8 & 65 & 64 \\
\hline 9 & 70 & 64 \\
\hline 10 & 70 & 64 \\
\hline 11 & 70 & 64 \\
\hline 12 & 70 & 64 \\
\hline 13 & 70 & 64 \\
\hline 14 & 70 & 70 \\
\hline 15 & 70 & 70 \\
\hline 16 & 70 & 70 \\
\hline 17 & 75 & 70 \\
\hline 18 & 75 & 70 \\
\hline 19 & 80 & 70 \\
\hline 20 & 80 & 73 \\
\hline 21 & 80 & 79 \\
\hline 22 & 80 & 79 \\
\hline 23 & 80 & 79 \\
\hline 24 & 80 & 79 \\
\hline 25 & 80 & 79 \\
\hline 26 & 80 & 79 \\
\hline 27 & 80 & 79 \\
\hline 28 & 85 & 79 \\
\hline 29 & 90 & 88 \\
\hline 30 & 90 & 88 \\
\hline 31 & 90 & 88 \\
\hline & & \\
\hline
\end{tabular}

Grafik 2 Hubungan Kreativitas Terhadap Kemampuan Memecahkan Masalah

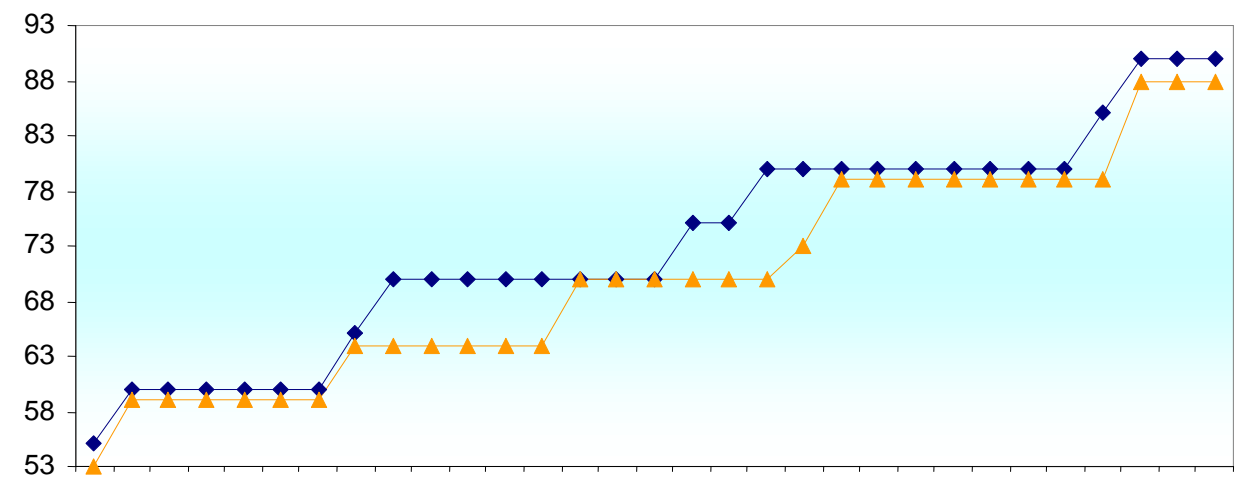

siswa 10 siswa 12 siswa 14 siswa 16 siswa 18 siswa 20 siswa 22 siswa 24 siswa 26 siswa 28 siswa 30 siswa 32 siswa 34 siswa 36 siswa 38 siswa 40 
Kesimpulannya berdasarkan tabel 8 diketahui bahwa terdapat dua anak yang termasuk dalam kategori rendah untuk kreativitasnya namun dua anak tersebut termasuk dalam kategori tinggi untuk kemampuan memecahkan masalahnya, namun hal ini tidak berdapak negatif, karena nilainya saling berhubungan. Secara keseluruhan apabila di konsultasikan dengan grafik 1 yaitu grafik regresi linier, maka nilai-nilai tersebut terdapat korelasi. Artinya titik titik yang merupakan garis lurus menyudut, menunjukkan adanya korelasi positif dan ada hubungan yang erat antara kedua variabel yang dikorelasikan.

\section{Penutup}

\subsection{Simpulan}

Berdasarkan pengujian hipotesis dan analisis data penelitian, maka dalam penelitian ini dapat mengambil suatu kesimpulan sebagai berikut:

Terdapat pengaruh positif antara kreativitas siswa terhadap kemampuan memecahkan masalah fisika pokok bahasan optik fisis pada siswa kelas XI-A SMA 3 Jombang yaitu diperoleh korelasi $r$ sebesar 0,752 dan persamaan garis regresi linier $Y=8,37+0,85 X$

Tingkat kreativitas siswa memberikan peranan yang nyata terhadap kemampuan memecahkan masalah dalam pelajaran fisika dan proses belajar mengajar dalam seting pembelajaran kontekstual sangat membantu untuk mengetahui kreativitas siswa.

\subsection{Saran}

Dengan memperhatikan hasil penelitian di atas, agar kegiatan belajar fisika lebih baik, efektif dan diminati oleh siswa, maka saran yang dapat diberikan dalam rangka ikut serta mendukung salah satu usaha untuk meningkatkan hasil belajar siswa adalah dapatnya dikembangkan kreativitas siswa dengan pengembangan laboratorium dalam proses belajar mengajar, sehingga dapat tercipta komunikasi dengan lingkungan dan membawa siswa lebih percaya diri yang akhirnya dapat mendorong timbulnya kreativitas anak serta memberikan pengaruh positif terhadap kemampuan memecahkan masalah.

\section{Daftar Pustaka}

[1] Arikunto, Suharsimi. 1990. DasarDasar Evaluasi Pendidikan. Jakarta: Bina Aksara.

[2] Arikunto, Suharsimi. 1997. Prosedur Penelitian (Suatu Pendekatan). Jakarta: Bina Reneka Cipta.

[3] Abdullah, Mikrajudin. 2004. Sains Fisika SMA untuk kelas XI. Jakarta: Erlangga

[4] AS. Munandar dkk. 1990. Memupuk Bakat dan Kreativitas Siswa Sekolah Menengah. Jakarta: Gramedia.

[5] Coleman, Hammen. 1985. On The Role of Creative Thinking in Problem Posing. Englewood Clifft New Jersey: Prentice Hall, Inc

[6] Fatichatunnaiyirah. 2004. Identifikasi Proses Berpikir Kreatif Siswa Menggunakan Model Wallas Dalam Pengajuan Masalah Matematika Dengan Informasi Berupa Teks Di kelas I-A SMPN 26 Surabaya. Skripsi tidak dipublikasikan. Surabaya: Unmuh

[7] Morgan, Guilford T.et. al. 1986. Introduction to Educational Psychologi. 7 th ed. St Paul: Wset Publ. Co

[8] Munandar, S.C.U. 1987. Mengembangkan Bakat Dan Kreativitas Anak Sekolah. Jakarta: Gramedia

[9] ........2002. Kreativitas dan Keterbakatan Strategi Mewujudkan Potensi Kreativitas Dan Bakat. Jakarta: PT. Gramedia Pustaka Utama [10]Pengalaman Sepuluh Tokoh Kreativitas Indonesia, 2001. Mengembangkan Kreativitas. Jakarta: Pustaka Popular Obor. 